\title{
Glucosylceramide Synthase Is a Novel Biomarker of Midostaurin-Induced Cytotoxicity in Non-Mutant FLT3 Positive Acute Myeloid Leukemia Cells
}

\author{
Glukozilseramid Sentaz Mutant Olmayan FLT3 Pozitif Akut Miyeloid Lösemi \\ Hücrelerinde Midostaurin İlişkili Sitotoksisitenin Yeni Bir Biyobelirtecidir
}

\author{
Hande Nur Şahin' ${ }^{1}$, Aysun Adan' ${ }^{1}$ (D) \\ 'Department of Molecular Biology and Genetics, Faculty of Life and Natural Sciences, Abdullah Gul University, Kayseri, Turkey
}

ORCID ID: H.N.S. 0000-0002-2382-3160; A.A. 0000-0002-3747-8580

Cite this article as: Şahin HN, Adan A. Glucosylceramide synthase is a novel biomarker of midostaurin-induced cytotoxicity in non-mutant FLT3 positive acute myeloid leukemia cells. Experimed 2021; 11(3): 149-55.

\begin{abstract}
Objective: Glucosylceramide (GC) synthesized by glucosylceramide synthase (GCS) favors cell survival and proliferation in many cancers. However, it's role in Fms-like tyrosine kinase 3 (FLT3) non-mutant Acute Myeloid Leukemia (AML) pathogenesis is not clarified. Midostaurin, a multi-kinase inhibitor, clinically benefits FLT3-mutated AML, however, its clinical efficacy is under-estimated in FLT3 non-mutant AML. This study aimed to investigate the efficacy of combination of midostaurin with GCS inhibitor in FLT3 AML cell carrying wild-type FLT3 and the underlying molecular mechanisms.
\end{abstract}

Material and Method: Cytotoxic and cytostatic effects of midostaurin, PDMP (GCS inhibitor) alone and in combination on THP1 cells were determined by MTT assay and flow cytometric propidium iodide $(\mathrm{PI})$ staining, respectively. Calcusyn software was used to calculate combination indexes (Cls). GCS expression was checked by western blot.

Results: Midostaurin downregulated GCS. Simultaneous inhibition of FLT3 and GCS resulted in suppression of cell proliferation as compared to untreated control. Combinations showed synergistic cytotoxic effects $(\mathrm{Cl}<1)$. Co-treatments increased cell cycle population at $\mathrm{G} 2 / \mathrm{M}$ phase.

Conclusion: Inhibition of GCS enhances the efficacy of midostaurin in FLT3 non-mutant AML, which could be a novel therapeutic approach to increase midostaurin's limited usage in the clinic after detailed mechanistic studies.

Keywords: Cell cycle, FLT3 non-mutant AML, glucosylceramide synthase, midostaurin öz

Amaç: Glukozilseramid sentaz (GSS) tarafından sentezlenen glukozilseramid (GS) birçok kanser türünde hücre yaşamını ve proliferasyonunu sağlamaktadır. Ancak, mutant olmayan Fms-benzeri tirozin kinase 3 (FLT3) pozitif akut miyeloid lösemi (AML) patogenezindeki rolü açıklanmamıştır. Çoklu kinaz inhibitörü olan midostaurin mutant FLT3 AML tedavisinde etkili olmasına rağmen mutant olmayan FLT3 pozitif AML'deki klinik etkisi gözden kaçırılmıştır. Bu çalışmada, midostaurinin GSS inhibitörü ile kombinasyonunun yabanıl tip FLT3 ifadesine sahip AML hücrelerindeki etkisinin belirlenmesi ve moleküler mekanizmalarının açıklanması amaçlanmıştır.

Gereç ve Yöntem: Midostaurin, PDMP (GSS inhibitörü) ve kombinasyonların THP1 hücreleri üzerindeki sitotoksik ve sitostatik etkileri sırasıyla MTT testi ve PI boyaması ile akım sitometri kullanılarak belirlenmiştir. Kombinasyon indeksleri (CI) Calcusyn programı ile hesaplanmıştır. GSS ifadesi western blot ile belirlenmiştir.

Bulgular: Midostaurin GSS ifadesini baskılamıştır. FLT3 ve GSS'ın birlikte inhibe edilmesi kontrolle karşılaştırıldığında hücre çoğalmasını baskılamıştır. Kombinasyonlar sinerjistik sitotoksik etki göstermiş̧ir $(\mathrm{Cl}<1)$. Kombinasyon hücre döngüsünün $\mathrm{G} 2 / \mathrm{M}$ fazındaki hücre populasyonunu arttırmıştır.

Sonuç: Mutant olmayan FLT3 AML'de GSS inhibisyonunun midostaurin'in etkisini arttırdığı saptanmıştır. Detaylı mekanizma çalışmaları yapıldıktan sonra kombinasyon tedavisinin midostaurin'in sınırlı klinik kullanımını arttırması açısından yeni bir yaklaşım olabileceği düşünülmektedir.

Anahtar Kelimeler: Hücre döngüsü, FLT3 mutant olmayan AML, glukosilseramid sentaz, midostaurin 


\section{INTRODUCTION}

Acute myeloid leukemia (AML) is a genetically complex disorder, which results in different prognostic subgroups (1). Fmslike tyrosine kinase 3 (FLT3) gene is considered as the most important one among the altered genes in AML, leading to clinically problematic FLT3 positive AML subgroups in both newly diagnosed adult patients and pediatric AML (2).

The FLT3 gene is included in the receptor tyrosine kinase family and commonly found on the plasma membrane of hematopoietic stem and early progenitor cells and over-expressed or mutated on a high percentage of AML blasts (3). Dimerization and activation of FLT3 is induced after binding of FLT3 ligand, which leads to activated downstream RAS, PI3K/AKT and STAT5 signaling pathways involved in cell proliferation and inhibition of apoptosis $(3,4)$. FLT3 receptor and its downstream pathways become constitutively active as a result of two common FLT3 mutations, which are found in tyrosine kinase domain (TKD) and within its juxtamembrane domain (internal tandem duplication, ITD) $(2,4)$. Therefore, development of new small molecule inhibitors has dramatically changed the treatment course of FLT3 positive AML after defining the critical role of FLT3 signaling in disease pathogenesis. FLT3 inhibitors include first generation inhibitors such as midostaurin and sorafenib and next generation inhibitors such as crenolanib and gilteritinib, which differ in their specificity and potency (5). Among these inhibitors, midostaurin (PKC412) was the first one clinically approved for the treatment of newly diagnosed FLT3-mutation carrying patients in combinations with standard treatment protocols (6). However, some clinical trials revealed that midostaurin is also effective in non-mutant FLT3 positive AML, since $70-100 \%$ of AML patients overexpress FLT3 and it has multiple cellular targets in addition to FLT3 $(7,8)$. Molecular studies investigating this transient effect of midostaurin in non-mutant FLT3 AML are very scarce, which clearly indicated that FLT3-independent molecules or pathways might have a role to regulate its efficacy. In a study, ERK and KIT kinases have been shown to be targeted by midostaurin and their pharmacological inhibition enhanced its effect (9). In another study, MEK was identified as a midostaurin target and co-inhibition of MEK and FLT3 gave promising results (10). Therefore, we suggest that one of the mechanisms contributing to midostaurin's efficacy in non-mutant FLT3 AML could be the glucosylceramide synthase (GCS) enzyme involved in ceramide (Cer) catabolism, which has many therapeutic targets in different cancers.

Sphingolipids including Cer and its phosphorylated or glycosylated forms determine the cell fate, which is either cell survival or cell death (11). Members of the sphingolipid family affect cancer initiation and progression by modulating cell growth, and division, apoptosis, metastasis and response to therapy (12). The central molecule Cer derived is known to be an apoptotic lipid whilst its glycosylated form glucosylceramide (GC) is involved in cell proliferation and drug resistance $(11,13)$. Cer produced via de novo or salvage pathway is transferred to cis-Golgi to be glycosylated by GSC, hence this enzyme with its anti-carcinogenic activities is shown to possess therapeutic importance in cancers
(14). Inhibition of GCS in head and neck cancer overcame resistance to cisplatin by downregulating p-glycoprotein and upregulating apoptotic proteins (15). In Chronic Myeloid Leukemia (CML) cells, GCS was found overexpressed in imatinib-resistant cells as compared to sensitive partners and targeting GCS sensitized resistant cells to imatinib (16). Delivery of Cer nanoliposomes plus simultaneous inhibition of GCS resulted in induction of the intrinsic pathway of apoptosis in natural killer cell leukemia (17). Therefore, investigation of the involvement of GCS in midostaurin's effect on non-mutant FLT3 AML could open a new route to understand midostaurin's observed clinical activity and provide a novel target.

In this study, we hypothesized that inhibiting GCS in combination with midostaurin would enhance midostaurin's antileukemic activity in THP1 cells for the first time, and we could suggest a possible combination approach.

\section{MATERIAL AND METHOD}

\section{Chemicals and Agents}

MTT and midostaurin were commercially supplied (Sigma-Aldrich, USA). 1-phenyl-2-decanoylamino-3-morpholino-1-propanol (PDMP) was obtained from Cayman Chemicals (Ann Arbor, $\mathrm{MI}$, USA). Stock solutions (10 mM in dimethyl sulfoxide (DMSO)) were prepared, which do not contain more than $0.01 \%$ DMSO in culture. RPMI 1640 growth medium and all ingredients required for complete growth medium (Penicillin-streptomycin and fetal bovine serum) were obtained from Invitrogen (Paisley, UK).

\section{Cell Lines and Culture Conditions}

THP1 cell line, representing non-mutant/wild type FLT3 carrying AML cell line, was purchased from German Collection of Microorganisms and Cell Cultures (Germany, DSMZ) and cultured and maintained in RPMI-1640 growth medium (with L-glutamine) including $10-20 \%$ fetal bovine serum (FBS) and $1 \%$ penicillin-streptomycin up to 15 passages at $37^{\circ} \mathrm{C}$ in a $5 \%$ $\mathrm{CO}_{2}$ incubator.

\section{Cell Viability Assay}

Cell viability was analyzed by the standard MTT protocol in response to increasing concentrations of midostaurin (100-1000 $\mathrm{nM})$, and PDMP (1-80 $\mu \mathrm{M})$ on THP1 cells (18). $1 \times 10^{4}$ cells/well were seeded in 96-well plates for $48 \mathrm{~h}$. Following treatments, a $20 \mu \mathrm{l} \mathrm{MTT}$ solution $(5 \mathrm{mg} / \mathrm{mL}$, Sigma Aldrich) was added. Then, absorbances were recorded at $570 \mathrm{~nm}$ using a spectrophotometer. Based on the cell proliferation graphs, $I_{50}$ values (concentration inhibiting cell growth by $50 \%$ ) for midostaurin and PDMP were calculated by linear regression analysis using GraphPad software (San Diego, CA).

\section{Combination Index (CI) Analysis}

Midostaurin (200-800 nM) was combined with PDMP (10-40 $\mu$ M) at a fixed molar ratio. After $48 \mathrm{~h}$ of exposure, cell survival was assessed by the standard MTT assay. The method of Chou and Talalay was used to define whether combinations lead to synergism $(\mathrm{Cl}<1)$, additivity $(\mathrm{Cl}: 1.0-1.1)$ or antagonism $(\mathrm{Cl}>1.1)$ using CalcuSyn software (Biosoft, Cambridge, United Kingdom) $(19,20)$. 


\section{Cell Cycle Analysis}

$7.5 \times 10^{5}$ cells $/ 2 \mathrm{ml}$ were treated with midostaurin $(400-800 \mathrm{nM})$, PDMP $(20-40 \mu \mathrm{M})$ and their combinations (synergistic combinations were chosen based on $\mathrm{Cl}$ analysis) for $48 \mathrm{~h}$. Then, the cells were fixed with cold ethanol overnight at $-20^{\circ} \mathrm{C}$. The cells were treated with RNase-A $\left(200 \mu \mathrm{g} / \mathrm{ml}\right.$, Sigma Aldrich) at $37^{\circ} \mathrm{C}$ for $30 \mathrm{~min}$ and then with propidium iodide (PI) $(1 \mathrm{mg} / \mathrm{ml}$, Sigma Aldrich) at room temperature for 10-15 minutes (18). Cell cycle analysis was carried out by BD FACSCalibur flow cytometer (BD Biosciences). The results were analyzed using BD FACSDiva ${ }^{\mathrm{TM}}$ (BD Biosciences).

\section{Western Blot Analysis}

$5 \times 10^{6}$ cells were incubated with midostaurin ( 200 and $400 \mathrm{nM}$ ) for $48 \mathrm{~h}$ to detect the changes in the expression of GCS by western blot. After cell lysis in the RIPA buffer (Sigma-Aldrich, USA), protein amounts were detected with RC DC ${ }^{\mathrm{TM}}$ Protein Assay Kit (Bio-Rad, USA). $30 \mu \mathrm{g}$ protein was loaded to SDS-PAGE and separated proteins were transferred to PVDF membranes. Primary antibodies for GCS (1:3000, Novus Biologicals, USA) and Beta Actin (1:3000, Cell Signaling, USA) were used to detect the proteins and conjugated with secondary antibodies (1:10000, Jackson ImmunoResearch, USA). The protein bands were visualized with Pierce ${ }^{\mathrm{TM}} \mathrm{ECL}$ Western Blotting Substrate kit (Thermo Scientific ${ }^{T \mathrm{M}}, \mathrm{USA}$ ). Densitometric analysis of immunoreactive bands was carried out by the imaging software (Bio-Rad, ChemiDoc, Image LabTM 3.0).

\section{Statistical Analysis}

Three independent experiments were done where the results are expressed as mean \pm standard deviation (SD). GraphPad Prism 6.0 was used for statistical analysis. One-way ANOVA was applied followed by Dunnett's or Tukey's multiple comparisons tests. $p<0.05$ was accepted as statistically significant.

\section{RESULTS}

Midostaurin Decreased Glucosylceramide Synthase Level in THP1 Cells

Changes in GCS protein level in response to sub-toxic concentrations of midostaurin (200 and $400 \mathrm{nM}$ ) were analyzed.
$400 \mathrm{nM}$ midostaurin caused a 0.5 -fold decrease in GCS expression compared with the untreated control group (Figure 1) although $200 \mathrm{nM}$ midostaurin did not affect GCS expression significantly. Therefore, it could be suggested that GCS might be a critical enzymatic target involved in non-mutant FLT3 positive AML pathogenesis.

\section{Co-inhibition of FLT3 and GCS Exerted Synergistic Cytotoxic Effect in THP1 Cells}

It was previously shown that midostaurin alone inhibited the viability of THP1 cells with an $\mathrm{IC}_{50}$ : $916 \mathrm{nM}$ (Figure 2A) (21). PDMP alone did not affect leukemic cell viability significantly up to $40 \mu \mathrm{M}$ and its $\mathrm{IC}_{50}$ was approximately $63 \mu \mathrm{M}$ (Figure 2B). To determine whether the inhibition of GCS by PDMP could affect anti-proliferative action of midostaurin, THP1 cells were treated with midostaurin plus PDMP by using their sub-toxic concentrations for $48 \mathrm{~h}$. As shown in Figure $2 \mathrm{C}$, at midostaurin concentrations of $400 \mathrm{nM}$ and $800 \mathrm{nM}$, viability of THP1 cells exposed to 20 and $40 \mu \mathrm{M}$ PDMP was significantly inhibited as compared to the control. (Figure $2 \mathrm{C}$ ). Viability of the cells treated with $800 \mathrm{nM}$ midostaurin in combination with $40 \mu \mathrm{M}$ PDMP was significantly lower than that of the cells treated with 800 $\mathrm{nM}$ midostaurin alone (Figure $2 \mathrm{C}$ ). Cls were also calculated (Figure 2D). The combination of 400 and $800 \mathrm{nM}$ midostaurin with 20 and $40 \mu \mathrm{M}$ PDMP, respectively resulted in synergistic toxicity (Cls: 0.6 and 0.8 )

\section{Co-targeting FLT3 and GCS Arrested THP1 Cells at G2/M Phase}

To determine whether the enhanced midostaurin toxicity in the presence of PDMP was related to changes in distribution of cell cycle populations, we analyzed the cell cycle percentages of the cells treated with midostaurin and PDMP alone or their combinations based on CalcuSyn analysis. 400 and 800 $\mathrm{nM}$ midostaurin alone blocked cell cycle progression at the G2/M phase (20.1 and 36.4 vs $9.5 \%$, respectively) as shown in the previous study (21), whereas PDMP alone did not induce changes in any of the cell cycle phases as compared to control (Figure $3 \mathrm{~A}$ and Figure $3 \mathrm{~B}$ ). Both combinations stopped the cell cycle at the G2/M phase ( 37 and 37.1 vs $9.5 \%$, respectively) as
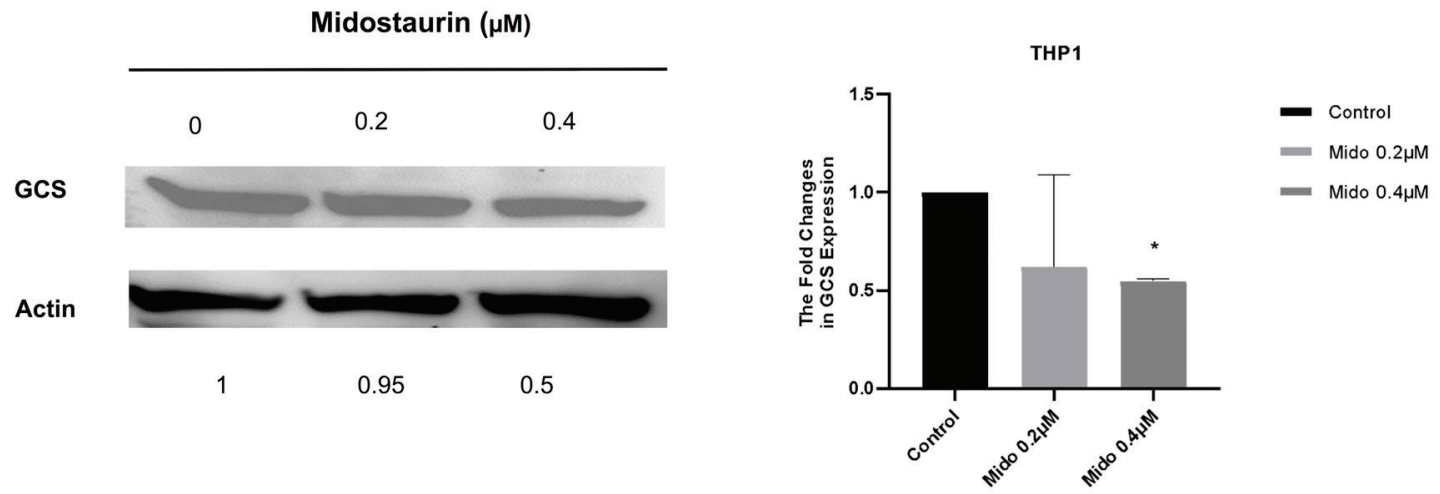

Figure 1. Western blot analysis of GCS expression in response to midostaurin in THP1 cells. The results from three independent experiments were given as mean \pm SD. ${ }^{*}$ p $<0.05$ vs. control. GCS: Glucosylcermide synthase; Mido: Midostaurin 


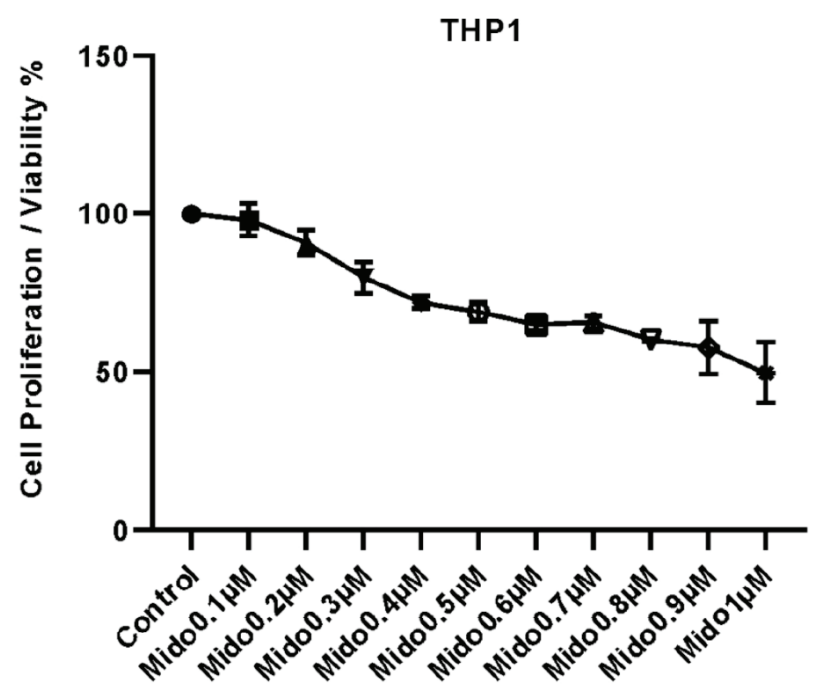

A.

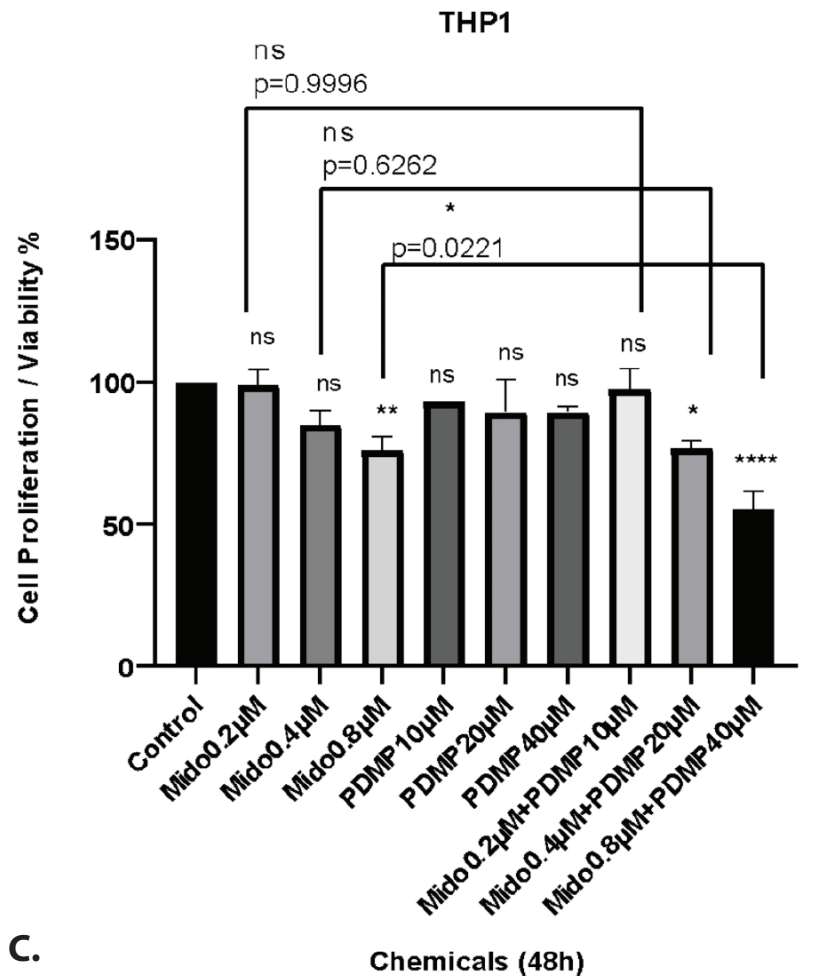

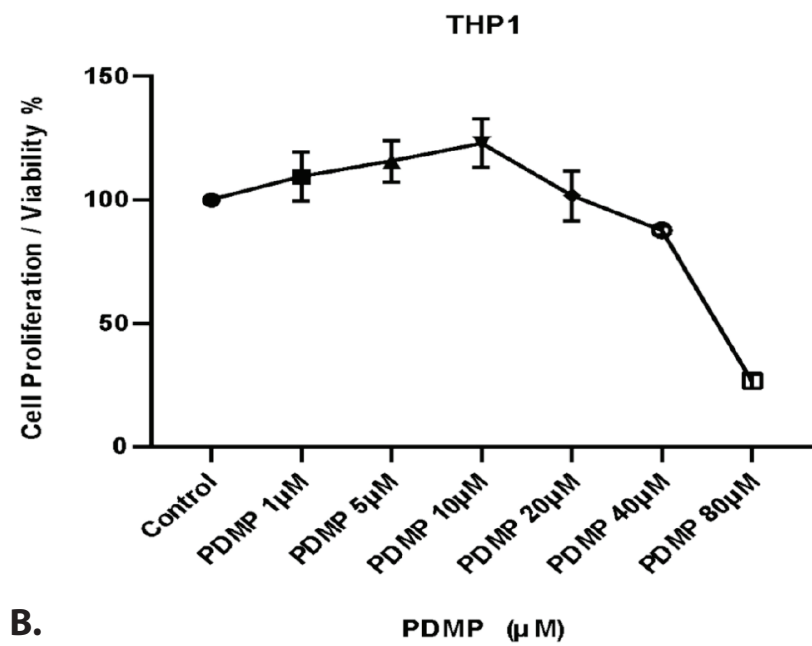

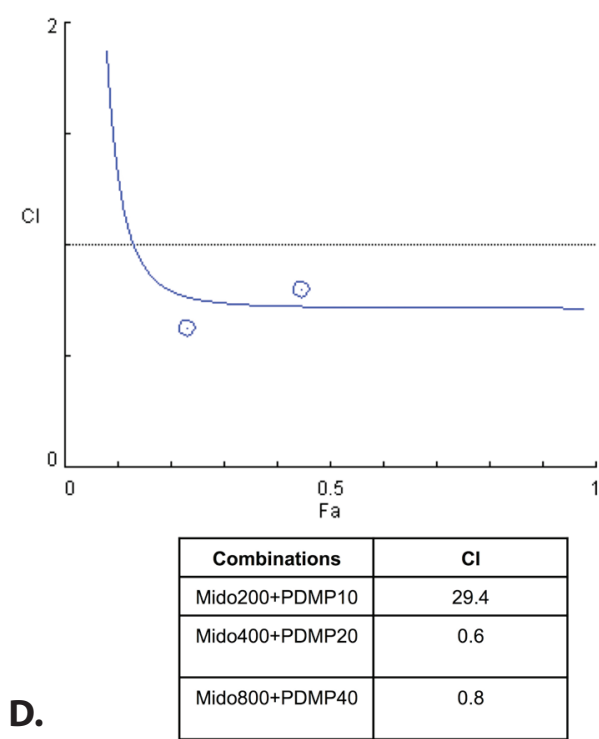

Figure 2. Anti-proliferative effects of midostaurin (A), PDMP (B) and combinations (C) in THP1 cells. Results are shown as means \pm SD of three experimental setups performed at different times. Calculation of $\mathrm{Cl}$ values based on the method of Chou and Talalay (D). ${ }^{*} p<0.05,{ }^{* *} p<0.005,{ }^{* * * *} p<0.0001$ versus control. Mido: Midostaurin

compared to control. $400 \mathrm{nM}$ midostaurin with $20 \mu \mathrm{M}$ PDMP arrested the cells at G2/M phase as compared to midostaurin alone (20.1\% and $37 \%$, respectively) (Figure $3 \mathrm{~A}$ and Figure $3 \mathrm{~B}$ ). These data further supported the enhancing effect of GCS inhibition on the cytotoxicity of midostaurin alone.

\section{DISCUSSION}

The roles of sphingolipid metabolism's intermediates including Cer and its modified forms in carcinogenesis and response to therapy have been extensively investigated (22). In this concept, we explored the role of GCS for the first time in mi- 

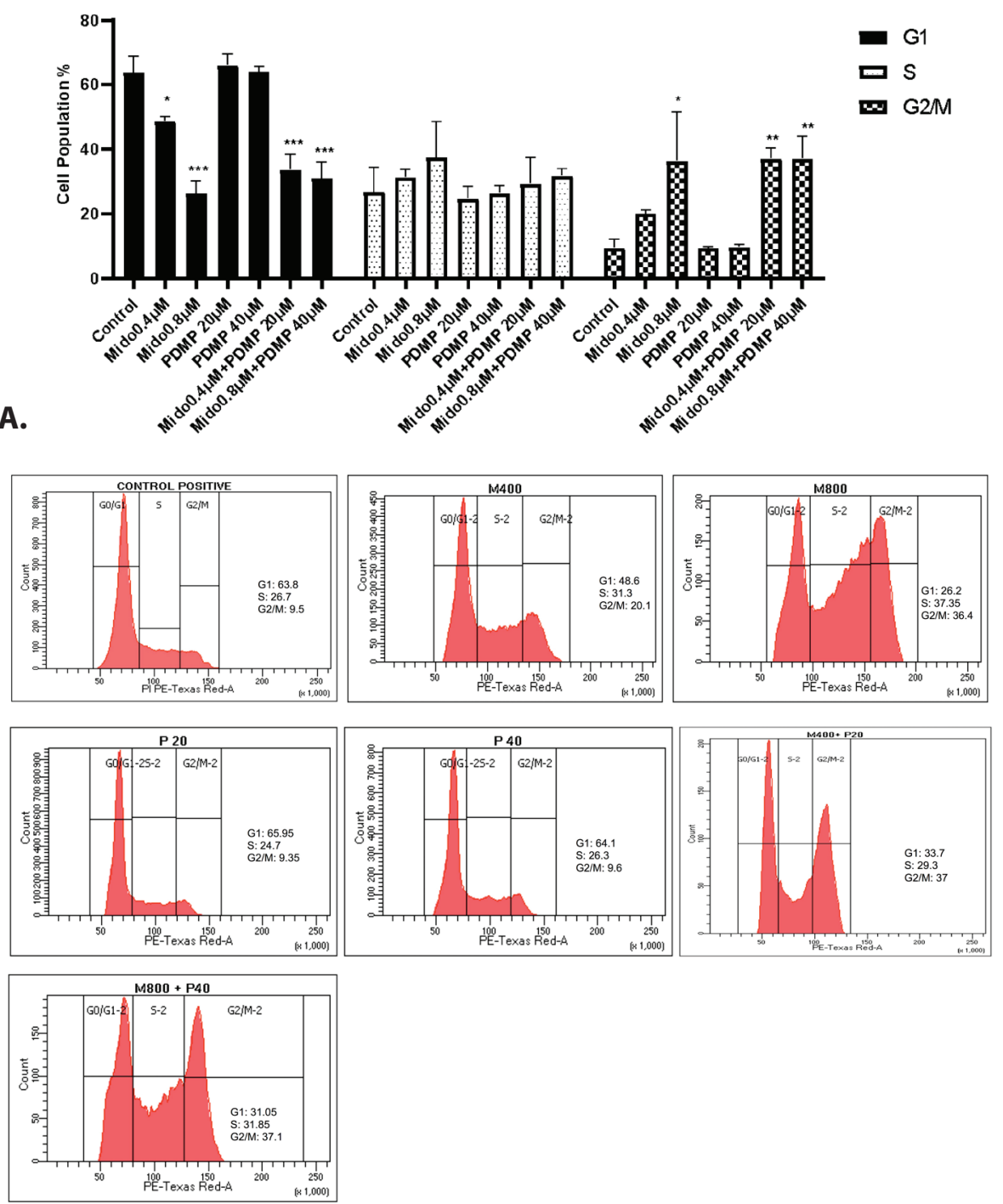

B.

Figure 3. Cell cycle distribution of THP1 cells treated with midostaurin, PDMP and combinations. Data are shown as the means \pm SD of three experimental setups performed at different times. ${ }^{*} p<0.05,{ }^{* *} p<0.005,{ }^{* * *} p<0.0005$ versus control. Mido: Midostaurin

dostaurin's anti-leukemic action in non-mutant FLT3 positive AML although its clinical approval has been granted for only patients carrying FLT3 mutations (23). Midostaurin's activity in non-mutant FLT3 AML patients was also encouraging based on a phase III trial (24), which could suggest the presence of FLT3-independent targets responsible for its broad activity as explained previously $(9,10)$.

GCS resides in golgi apparatus and catalyzes the conversion of Cer into GC by transferring UDP-glucose to Cer. GC is shown to be overexpressed in various cancers and found to be associated with increased cell proliferation and failed treatment response (14). In this study, we suggest that GCS could be associated with observed clinical response in phase studies and a new therapeutic target could be defined if its role in midostaurin's action is enlightened in non-mutant FLT3 positive AML.

The protein level of GCS was decreased after midostaurin treatment as compared to untreated cells (Figure 1) and untreated cells had also high GCS expression, suggesting that GCS could be involved in response to midostaurin treatment as well as having a role in non-mutant FLT3 positive AML pathogenesis. There are studies regarding the role of GCS in several hematological malignancies. In resistant chronic myeloid leukemias, 
GCS was shown to be upregulated $(16,25)$. Based on this result, THP1 cells were treated with midostaurin plus PDMP to determine the presence of any synergistic cytotoxic effect. The results suggested that midostaurin's growth inhibitory effect on THP1 cells was enhanced via showing synergistic inhibition of cell viability (Cls $<1$ for combinations) (Figure $2 \mathrm{C}$ and Figure 2D). Hence, GCS could be defined as a therapeutic target in THP cells, which is in accordance with the findings in several cancers. Inhibition of GCS by using a specific inhibitor together with chemotherapeutics sensitized resistant leukemia cells by increasing apoptosis (25). In prostate cancer cells, co-treatment with docetaxel and GCS inhibitor enhanced docetaxel's cytotoxic activity by inducing strong synergism (26). PDMP also potentiated the cytotoxic effect of dasatinib in CML cells with $\mathrm{Cl}$ values lower than 1 (27).

To further investigate the enhanced cytotoxicity of midostaurin induced by PDMP, cell cycle populations were quantified after treatment with midostaurin and PMDP alone and in combinations. The results showed that PDMP alone did not cause changes at cell cycle phases, however midostaurin alone arrested the cells at G2/M (Figure 3). This cytostatic effect of midostaurin was in accordance with studies comparing the effects of midostaurin on cell cycle distribution between non-mutant and mutant FLT3 positive AML and FLT3 wild type AML $(28,21)$. The studies related to cell cycle profiles of the leukemic cells treated with GCS inhibitors showed varying results based on the leukemia type. In K562 CML cells, PDMP exposure resulted in G1 arrest and it caused more accumulation together with imatinib (16). Another GCS inhibitor PPPP did not change cell cycle profiles of leukemic cells alone, however, combination with vincristine increased G2/M population (29). In this study, co-treatments induced G2/M arrest as compared to the control or midostaurin alone (Figure 3). There are very limited studies investigating the contribution of Cer or its metabolites to midostaurin's effect in cancer in which liposomal Cer treatment or sphingosine kinase-1 inhibition increased midostaurin's activity $(30,21)$.

In conclusion, midostaurin's cytotoxic activity is enhanced in the presence of PDMP, which supported the involvement of GCS in midostaurin treatment and non-mutant FLT3 positive AML pathogenesis through inducing synergistic cell cycle arrest. Even though this preliminary study could suggest a new target of midostaurin, it is still needed to elucidate the relationship between midostaurin and GCS mechanistically. It would be suggested to investigate the role of signaling pathways leading to cell death and to analyze cell cycle regulators involved in G2/M phase regulation in response to co-treatments. Pre-clinical in vitro models, in vivo mouse studies and ex vivo patient samples could be studied to reveal the expression level of GCS after midostaurin treatment.

Acknowledgment: The authors acknowledge Genome and Stem Cell Center of Erciyes University for flow cytometry facility. We thank Esma Saraymen, the specialist, for her technical assistance during flow cytometry measurements.
Ethics Committee Approval: Ethics committee approval is not required because of no material or experimental animal that would require permission.

Peer-review: Externally peer-reviewed.

Author Contributions: Conception/Design of Study - A.A.; Materials - H.N.Ş., A.A.; Data Collection - H.N.Ş., A.A.; Analysis and/or Interpretation - H.N.Ş., A.A.; Drafting Manuscript - H.N.Ş., A.A.; Final Approval and Accountability - H.N.Ş., A.A.

Conflict of Interest: The authors have no conflict of interest to declare.

Financial Disclosure: The authors declared that this study has received no financial support.

Teşekkür: Akım sitometri kullanımı için Erciyes Üniversitesi Genom ve Kök Hücre Merkezi'ne teşekkür ederiz. Ayrıca, akım sitometri ölçümleri sırasında teknik yardımları için uzman Esma Saraymen'e teşekkür ederiz.

Etik Komite Onayı: Bu calışmada, etik komite iznine gerek duyulacak bir materyal ya da deney hayvanı kullanılmamıştır.

Yazar Katkıları: Çalışma Konsepti/Tasarımı - A.A.; Materyal - H.N.Ş., A.A.; Veri Toplama - H.N.Ş., A.A.; Veri Analizi/Yorumlama - H.N.Ş., A.A.; Yazma - H.N.Ş., A.A.; Son Onay ve Sorumluluk - H.N.Ş., A.A.

Çıkar Çatışması: Yazarlar çıkar çatışması bildirmemişlerdir.

Finansal Destek: Yazarlar bu çalışmada finansal destek almadıklarını beyan etmişlerdir.

\section{REFERENCES}

1. Blum WG, Mims AS. Treating acute myeloid leukemia in the modern era: A primer. Cancer 2020; 126(21): 4668-77. [CrossRef]

2. Ambinder AJ, Levis M. Potential targeting of FLT3 acute myeloid leukemia. Haematologica 2021; 106(3): 671-81. [CrossRef]

3. Kennedy VE, Smith CC. FLT3 Mutations in acute myeloid leukemia: Key concepts and emerging controversies. Front Oncol 2020; 10: 612880. [CrossRef]

4. Daver N, Schlenk RF, Russell NH, Levis MJ. Targeting FLT3 mutations in AML: review of current knowledge and evidence. Leukemia 2019; 33: 299-312. [CrossRef]

5. Antar Al, Otrock ZK, Jabbour E, Mohty M, Bazarbachi A. FLT3 inhibitors in acute myeloid leukemia: ten frequently asked questions. Leukemia 2020; 34(3): 682-96. [CrossRef]

6. Stone RM, Mandrekar SJ, Sanford BL, Laumann K, Geyer S, et al. Midostaurin plus Chemotherapy for Acute Myeloid Leukemia with a FLT3 Mutation. N Eng J Med 2017; 377(5): 454-64. [CrossRef]

7. Fischer T, Stone RM, Deangelo DJ, Galinsky I, Estey E, et al. Phase IIB trial of oral Midostaurin (PKC412), the FMS-like tyrosine kinase 3 receptor (FLT3) and multi-targeted kinase inhibitor, in patients with acute myeloid leukemia and high-risk myelodysplastic syndrome with either wild-type or mutated FLT3. J Clin Oncol 2010; 28(28): 4339-45. [CrossRef]

8. Stone RM, Fischer T, Paquette R, Schiller G, Schiffer CA, et al. Phase IB study of the FLT3 kinase inhibitor midostaurin with chemotherapy in younger newly diagnosed adult patients with acute myeloid leukemia. Leukemia 2012; 26(9): 2061-8. [CrossRef] 
9. Weisberg E, Meng C, Case AE, Tiv HL, Gokhale PC et al. Effects of the multi-kinase inhibitor midostaurin in combination with chemotherapy in models of acute myeloid leukaemia. J Cell Mol Med 2020; 24(5): 2968-80. [CrossRef]

10. Morales ML, Arenas A, Ortiz-Ruiz A, Leivas A, Rapado I, et al. MEK inhibition enhances the response to tyrosine kinase inhibitors in acute myeloid leukemia. Sci Rep 2019; 9(1): 18630. [CrossRef]

11. Giussani P, Tringali C, Riboni L, Viani P, Venerando B. Sphingolipids: key regulators of apoptosis and pivotal players in cancer drug resistance. Int J Mol Sci 2014; 15: 4356-92. [CrossRef]

12. Truman JP, Garcia-Barros M, Obeid LM, Hannun YA. Evolving concepts in cancer therapy through targeting sphingolipid metabolism. Biochim Biophys Acta 2014; 1841: 1174-88. [CrossRef]

13. Morad SA, Cabot MC. Ceramide-orchestrated signalling in cancer cells. Nat Rev Cancer 2012; 13: 51-65. [CrossRef]

14. Kartal Yandım M, Apohan E, Baran Y. Therapeutic potential of targeting ceramide/glucosylceramide pathway in cancer. Cancer Chemother Pharmacol 2013; 71(1): 13-20. [CrossRef]

15. Roh JL, Kim EH, Park JY, Kim JW. Inhibition of Glucosylceramide Synthase Sensitizes Head and Neck Cancer to Cisplatin. Mol Cancer Ther 2015; 14(8): 1907-15. [CrossRef]

16. Baran Y, Bielawski J, Gunduz U, Ogretmen B. Targeting glucosylceramide synthase sensitizes imatinib-resistant chronic myeloid leukemia cells via endogenous ceramide accumulation. Cancer Res Clin Oncol 2011; 137(10): 1535-44. [CrossRef]

17. Watters RJ, Fox TE, Tan SF, Shanmugavelandy S, Choby JE, et al. Targeting glucosylceramide synthase synergizes with C6-ceramide nanoliposomes to induce apoptosis in natural killer cell leukemia. Leuk Lymphoma 2013; 54(6): 1288-96. [CrossRef]

18. Adan A, Baran Y. The pleiotropic effects of fisetin and hesperetin on human acute promyelocytic leukemia cells are mediated through apoptosis, cell cycle arrest, and alterations in signaling networks. Tumor Biology 2015; 36(11): 8973-84. [CrossRef]

19. Chou TC. Drug combination studies and their synergy quantification using the Chou-Talalay method. Cancer Res 2010; 70: 440-6. [CrossRef]

20. Casagrande N, Borghese C, Favero A, Vicenzetto C, Aldinucci D. Trabectedin overcomes doxorubicin-resistance, counteracts tumor-immunosuppressive reprogramming of monocytes and decreases xenograft growth in Hodgkin lymphoma. Cancer Lett 2021; 500: 182-93. [CrossRef]
21. Sahin HN, Adan A. Combinatorial effect of midostaurin and sphingosine kinase-1 inhibitor on FLT3 wild type acute myeloid leukemia cells. Turkish Journal of Biochemistry 2021; in press

22. Kroll A, Cho HE, Kang MH. Antineoplastic agents targeting targeting sphingolipid pathways. Front Oncol 2020; 10: 833. [CrossRef]

23. Levis M. Midostaurin approved for FLT3-mutated AML. Blood 2017; 129(26): 3403-6. [CrossRef]

24. Dohner H, Sierra J, Stone R, Hoenekopp A, Berkowitz N, et al. Trial in progress: A phase 3 , randomized, double-blind study of midostaurin in combination with chemotherapy and as single-agent maintenance therapy in newly diagnosed patients with FLT3 mutation-negative acute myeloid leukemia (AML). Clin Lymphoma Myeloma Leuk 2018; 18(Suppl 1): S206-7. [CrossRef]

25. Salustiano EJ, da Costa KM, Freire-de-Lima L, Mendonça-Previato L, Previato JO. Inhibition of glycosphingolipid biosynthesis reverts multidrug resistance by differentially modulating $A B C$ transporters in chronic myeloid leukemias. J Biol Chem 2020; 295(19): 645771. [CrossRef]

26. Bassoy EY, Baran Y. Bioactive sphingolipids in docetaxel-induced apoptosis in human prostate cancer cells. Biomed Pharmacother 2012; 66(2): 103-10. [CrossRef]

27. Gencer EB, Ural AU, Avcu F, Baran Y. A novel mechanism of dasatinib-induced apoptosis in chronic myeloid leukemia; ceramide synthase and ceramide clearance genes. Ann Hematol 2011; 90(11): 1265-75. [CrossRef]

28. Odgerel T, Kikuchi J, Wada T, Shimizu R, Futaki K, et al. The FLT3 inhibitor PKC412 exerts differential cell cycle effects on leukemic cells depending on the presence of FLT3 mutations. Oncogene 2008; 27(22): 3102-10. [CrossRef]

29. Olshefski RS, Ladisch S. Glucosylceramide synthase inhibition enhances vincristine-induced cytotoxicity. Int J Cancer 2001; 93(1): 131-8. [CrossRef]

30. Zhu Y, Wang C, Zhou Y, Ma N, Zhou J. C6 ceramide motivates the anticancer sensibility induced by PKC412 in preclinical head and neck squamous cell carcinoma models. J Cell Physiol 2018; 233(12): 9437-46. [CrossRef] 